\title{
Strategic control of cattle ticks: milk producers' perceptions
}

\author{
Controle estratégico do carrapato dos bovinos: percepção dos produtores de leite
}

Maria Alice Zacarias do Amaral ${ }^{1 *}$; Christiane Maria Barcellos Magalhães da Rocha ${ }^{2}$; João Luiz Faccini ${ }^{3}$; John Furlong ${ }^{4}$; Caio Márcio de Oliveira Monteiro ${ }^{5}$; Márcia Cristina de Azevedo Prata ${ }^{4}$

${ }^{1}$ Centro de Experimentação Animal, Instituto Oswaldo Cruz - FIOCRUZ

${ }^{2}$ Universidade Federal de Lavras - UFLA

${ }^{3}$ Departamento de Parasitologia, Universidade Federal Rural do Rio de Janeiro - UFRRJ

${ }^{4}$ Embrapa Gado de Leite, Empresa Brasileira de Pesquisa Agropecuária - EMBRAPA

${ }^{5}$ Universidade Federal de Juiz de Fora - UFJF

Received December 1, 2010

Accepted January 18, 2011

\begin{abstract}
In order to evaluate milk producers' knowledge about tests on tick sensitivity to acaricides, efficiency tests and strategic control, questionnaires were delivered to 670 producers. From these, 163 responses were received. These producers had sent ingurgitated female ticks to be subjected to tests on tick sensitivity to acaricides at Embrapa between 2001 and 2005. Most of the completed questionnaires came from the State of Minas Gerais, Brazil. After descriptive analysis and correlation of variables, it was found that $48.5 \%$ of the properties owned herds of up to 100 head of cattle and $57.3 \%$ of the producers belonged to a cooperative. Among the respondents, 157 (98.7\%) applied the acaricide indicated by the efficiency test, and $144(92.9 \%)$ said that they applied strategic control but incorrectly. There was improvement in some control stages. However, only $12(7 \%)$ showed comprehension of all the stages of strategic control. It was concluded that there is a need for continuing assistance, so as to achieve effective improvement in controlling Rhipicephalus (Boophilus) microplus.
\end{abstract}

Keywords: Rhipicephalus (Boophilus) microplus, knowledge, milk producers.

\section{Resumo}

Objetivando avaliar o conhecimento dos produtores de leite que usufruíram do teste de sensibilidade dos carrapatos aos carrapaticidas - teste de eficácia e controle estratégico - foram enviados questionários a 670 produtores. Desses, 163 foram respondidos. Esses produtores representam aqueles que enviaram fêmeas ingurgitadas para proceder aos testes de sensibilidade dos carrapatos aos carrapaticidas pela Embrapa, de 2001 a 2005. Dos respondidos, a maioria localiza-se no Estado de Minas Gerais. Após análise descritiva e cruzamento de variáveis, constatou-se que 48,5\% das propriedades possuem rebanho até 100 cabeças de gado; $57,3 \%$ produtores pertencem a uma cooperativa. Um total de 157 (98,7\%) entrevistados aplicou o acaricida indicado pelo teste de eficácia, e 144 (92,9\%) respondentes afirmaram ter seguido o controle estratégico, porém, não de forma correta, havendo, entretanto, melhora em algumas etapas do controle. No entanto, apenas $12(7 \%)$ demonstraram compreender todas as fases do controle estratégico, apesar de terem recebido informaçóes técnicas de como proceder com o controle. Conclui-se que há necessidade de assistência continuada para melhoria efetiva do controle de Rhipicephalus (Boophilus) microplus.

Palavras-chave: Rhipicephalus (Boophilus) microplus, conhecimento, produtores de leite.

\footnotetext{
${ }^{*}$ Corresponding author: Maria Alice Zacarias do Amaral

Centro de Experimentação Animal, Instituto Oswaldo Cruz - FIOCRUZ,

Av. Brasil, 436, CEP 21040-900, Rio de Janeiro - RJ, Brazil;

e-mail: Maria.alice@ioc.fiocruz.br
} 


\section{Introduction}

One of the biggest obstacles to cattle rearing around the world is losses due to endo and ectoparasites. In Brazil, the continental dimensions, size of the cattle stocks and climate favor proliferation of parasites, with repercussions on milk production and body weight gain among the animals (GRISI et al., 2002).

Angus (1996) stated that Rhipicephalus (Boophilus) microplus was the most important cattle tick worldwide, because of the economic losses that it causes. Jonsson et al. (2001) reported that cattle ticks caused major losses to the milk industry in Queensland, Australia. Some of these losses come from producers' and technicians' lack of knowledge about how to deal with the problem (JONSSON; MATSCHOSS, 1998). Because of the evolution of resistance to acaricides among cattle ticks and difficulty in developing new products, there is concern regarding the future of chemical control methods against ticks (GEORGE et al., 2004).

Motivated by this reality, Mendes et al. (2007) stated that one of the priorities in tick control is to avoid selection and proliferation of resistant populations. In this respect, in Costa Rica, Thullner et al. (2007) conducted studies on strategic rotation of acaricides in an attempt to delay the progress of resistance. Furthermore, in New Caledonia, an accumulation of resistance mechanisms against acaricides was observed among ticks (FREITAS et al., 2005).

The assessments that have been made so far have been limited to evaluations on product performance in certain regions of Brazil, such as Mato Grosso, São Paulo (SOARES et al., 2001); Paraná (SOUZA et al., 2003) and Pernambuco (SANTANA et al., 2001), and also in some other countries (JONSSON; HOPE, 2007). Given that linking between the problem of resistance and producers' comprehension is essential for changing the understanding of tick control methods, the aim of the present study was to investigate whether, with greater importance for the process of understanding and adopting strategic control methodologies, producers are in a position to understand and apply strategic control, in order to assess what information should be provided and how to do this.

\section{Material and Methods}

Data were gathered by means of semi-structured interviews between December 2005 and May 2006, using questionnaires that has previously been tested (ROJAS, 2001). The questions had the aim of obtaining information to characterize the farm properties and producers and ascertain producers' perceptions about information received from Embrapa Dairy Cattle, in order to quantify and quality their capacity to understand the control process and biology of cattle ticks.

Every producer $(n=670)$ that, between 2001 and 2005 had requested a test on tick sensitivity to acaricides from Embrapa Dairy Cattle, was sent the abovementioned questionnaire by post.

Content analysis (BARDIN, 1977) was performed on the results from the questionnaires, in accordance with the studies by Rocha (1995) and Rocha et al. (2006). The data were categorized (MINAYO, 2006) and a database was constructed using the Epidata 3.1 software.
To ascertain associations between qualitative variables of interest, the chi-square test $\left(\chi^{2}\right)$ was used, or Fisher's exact test when one of the cells of the contingency table presented fewer than five repetitions. For schooling levels, the chi-square test for trend was used.

The $95 \%$ confidence intervals were used to determine whether the associations were significant. These analyses were done using the Epi Info 6.04 software and the Statistical Package for the Social Sciences (SPSS, version 12.0).

Using the chi-square test, and taking questions/responses about biology and control to be dependent variables, associations between these and the following independent variables were investigated: 1) schooling level (elementary school, high school and university level); and 2) membership of a producers' cooperative (yes or no).

\section{Results and Discussion}

Out of the 670 producers investigated, only 163 provided responses to the questionnaires, thus totaling $24.3 \%$ of the sample studied. The producers studied were concentrated mostly in the southeastern region of Brazil (91\%), and mostly in the State of Minas Gerais (Table 1). This could probably be explained by their proximity to Embrapa Dairy Cattle, which is located in Juiz de Fora, Minas Gerais, and because this state is the biggest milk producer in Brazil (MILKPOINT, 2001). Since tick infestations cause losses of milk-producing animals and diminish milk production, milk producers felt the need to combat such infestations effectively. This motivated them to seek the test of tick sensitivity to acaricides, which is provided free of charge by Embrapa Dairy Cattle. Most of these producers $(57.3 \%)$, independent of the region, were organized into cooperatives, and 107 (66.5\%) of these producers were only involved in cattle rearing activities.

Among the farm properties analyzed, crossed cattle predominated $(80.4 \%)$, and $116(71.2 \%)$ of these farms had herds of up to 100 head of cattle, with a median daily milk production of $350 \mathrm{~L}$ (percentiles 170 and 790). On 143 farms (89.4\%), there were between one and ten horses (median $=4)$.

Among the interviewees, 92 (59.4\%) reported that they had observed fewer than 50 ticks per animal, independent of the type of activity developed on the property (dairy cattle rearing or subsistence farming) and of the cattle breed ( $p>0.05$ ) (Table 2). Although Veríssimo et al. (2004) demonstrated clear differences in tick resistance between cattle breeds, the infestation levels observed by the producers were similar.

Jonsson and Matschoss (1998) observed in Australia that most producers said that they had small quantities of ticks in their herds and, for this reason, they did not believe that it was necessary to implement a more specific and rational control program. When necessary, they used acaricides that were chosen according to advertising or the lowest price (HONER et al., 1990).

With regard to reasons for changing the acaricide that they were using, 87 (54.4\%) cited inefficiency of the products, in the same way as in the study by Rocha (2005). This finding demonstrates two worrying factors: use of an acaricide until reaching "saturation" and changing it without proper proof (through an acaricide test) that the inefficiency was due to resistance among the population. 
Table 1. Characterization of the farm properties and producers that used tests on acaricide efficiency against ticks and that participated in an investigation on strategic control of cattle ticks: perceptions of milk producers that used the test on tick sensitivity to acaricides at Embrapa Dairy Cattle, Juiz de Fora, Minas Gerais, between 2001 and 2005.

\begin{tabular}{|c|c|c|c|c|c|c|}
\hline \multirow{2}{*}{\begin{tabular}{|c|} 
Characteristics* \\
$\begin{array}{c}\text { Regions in which the farm } \\
\text { properties were located }\end{array}$ \\
\end{tabular}} & \multicolumn{4}{|c|}{ Categories } & \multicolumn{2}{|c|}{$\begin{array}{c}\text { Respondents** } \\
(\% \text { losses })\end{array}$} \\
\hline & $\begin{array}{l}\text { Southeast } \\
148(91 \%)\end{array}$ & $\begin{array}{c}\text { Northeast } \\
7(4 \%)\end{array}$ & $\begin{array}{c}\text { Center-West } \\
7(4 \%)\end{array}$ & $\begin{array}{l}\text { North } \\
1(1 \%) \\
\end{array}$ & - & $\begin{array}{l}163 \\
(0) \\
\end{array}$ \\
\hline Activities on the farm properties & $\begin{array}{c}\text { Livestock rearing } \\
107(66.5 \%)\end{array}$ & $\begin{array}{c}\text { Livestock rearing } \\
\text { with agriculture } \\
54(33.5 \%) \\
\end{array}$ & - & - & - & $\begin{array}{l}161 \\
(1.2)\end{array}$ \\
\hline $\begin{array}{c}\text { Farm properties that only } \\
\text { carried out livestock-rearing } \\
\text { activities }\end{array}$ & $\begin{array}{c}\text { Milk production } \\
84(78.5 \%)\end{array}$ & $\begin{array}{l}\text { Milk and beef } \\
\text { production } \\
16(14.9 \%) \\
\end{array}$ & $\begin{array}{c}\text { Beef production } \\
6(5.6 \%)\end{array}$ & $\begin{array}{c}\text { No indication of } \\
\text { activity } \\
1(1 \%) \\
\end{array}$ & - & $\begin{array}{c}107 \\
(34.4)\end{array}$ \\
\hline $\begin{array}{l}\text { Farm properties that carried } \\
\text { out livestock-rearing activities } \\
\text { together with agriculture }\end{array}$ & $\begin{array}{c}\text { Milk production } \\
40(71.4 \%)\end{array}$ & $\begin{array}{c}\text { Milk and beef pro- } \\
\text { duction } \\
11(19.6 \%) \\
\end{array}$ & $\begin{array}{c}\text { Beef production } \\
3(5.4 \%)\end{array}$ & $\begin{array}{c}\text { No indication of } \\
\text { activity } \\
2(3.6 \%)\end{array}$ & - & $\begin{array}{c}56 \\
(65.6)\end{array}$ \\
\hline Presence of horses & $\begin{array}{c}\text { Yes } \\
143(89.4 \%) \\
\end{array}$ & $\begin{array}{c}\text { No } \\
17(10.6 \%) \\
\end{array}$ & - & - & - & $\begin{array}{l}160 \\
(1.8) \\
\end{array}$ \\
\hline
\end{tabular}

*The percentages do not take losses into consideration; ${ }^{* *}$ Respondents - corresponding to the absolute number of producers that provided information; (\% losses) percentage of questionnaires in which this question remained unanswered, taking $\mathrm{n}=163$; ** More than one answer to this question was accepted.

According to Furlong and Martins (2000), it is important to ascertain whether there have been any failings in relation to preparation or application of the acaricide, since some of the ticks may survive because they have not been sufficiently reached by the product, and this may be confounded with resistance. Changes of acaricide had taken place as a result of efficiency tests on the product in the cases of only 43 of the farms (26.9\%).

Independent of the reasons that had led to changing the products, 128 producers $(84.2 \%)$ were using more than three products on their properties, without taking into account the mechanism of action, which may have favored the establishment of multiple resistance among the ticks. For this reason, Mendes et al. (2007) stated that there is an urgent need to assess the degree of resistance among ticks to groups of chemicals, in order to establish efficient management. Souza et al. (2003) observed that all the products presented efficacy of less than $95 \%$ on at least one farm property. Santos Junior et al. (2000) also observed in the state of Rio de Janeiro that populations resistant to all the acaricides used in the experiment were present. This resistance could be explained by an accumulation of mechanisms for tick resistance to acaricides, as also observed by Chevillon et al. (2007) in New Caledonia.

In the present study, it was found that changes of acaricide were being made with the proper indications outlined above. Only a few producers reported that they had not yet made any changes, i.e. only 24 farm properties (15.8\%) had used only one product. Among these were the following products: amidines $(n=10$; $42 \%)$; phosphorates $(\mathrm{n}=4 ; 18 \%)$; phenylpyrazoles $(\mathrm{n}=3 ; 12 \%)$; pyrethroids + phosphorates $(n=3 ; 12 \%)$; fluazuron $(n=3 ; 12 \%)$ and macrocyclic lactones $(n=1 ; 4 \%)$. These producers could now be advised to change the acaricide that was being used, for products with a different chemical basis and mode of action. There have been studies indicating that selection of resistant populations occurs very rapidly and, for this reason, the hypothesis that the same chemical basis, or different chemical bases with the same mechanisms of action, should not be used for more than six successive applications, as shown by Thullner et al. (2007), is starting to be accepted.

Among the 80 farm properties on which acaricide use for between zero and two years was reported, 24 producers (30\%) had changed the product following g recommendations from Embrapa Dairy Cattle (FURLONG; PRATA, 2003a), while $14(17.5 \%)$ had changed products for a variety of other reasons, such as human or animal poisoning. Also in relation to this total, $42(52.5 \%)$ stated that they had noticed that the product had lost its effectiveness within this two-year period. This may have occurred because frequent use of a product selected individuals that were better adapted, from which descendants with increasing degrees of resistance would be produced, to the point that most of the population would be descended from resistant ticks (FURLONG; MARTINS, 2000).

With regard to the use of personal protection equipment (PPE), 67.5\% of the producers affirmed that they used such equipment when applying acaricides, while only 15 (13.6\%) used PPE effectively, i.e. correctly and completely (Table 2 ) and $38(23.3 \%)$ said that they did not use it. Out of all the producers, $15(13.6 \%)$ did not answer the question. Among those that used PPE, 77 (70\%) said that they did so for safety reasons, while three $(2.7 \%)$ had only started to use PPE after a bad experience of poisoning. The remainder of the producers did not report the reasons for using PPE. 
Table 2. Characterization of the cattle tick control on the farm properties that participated in the investigation: perceptions of milk producers that used the test on tick sensitivity to acaricides at Embrapa Dairy Cattle, Juiz de Fora, Minas Gerais, between 2001 and 2005.

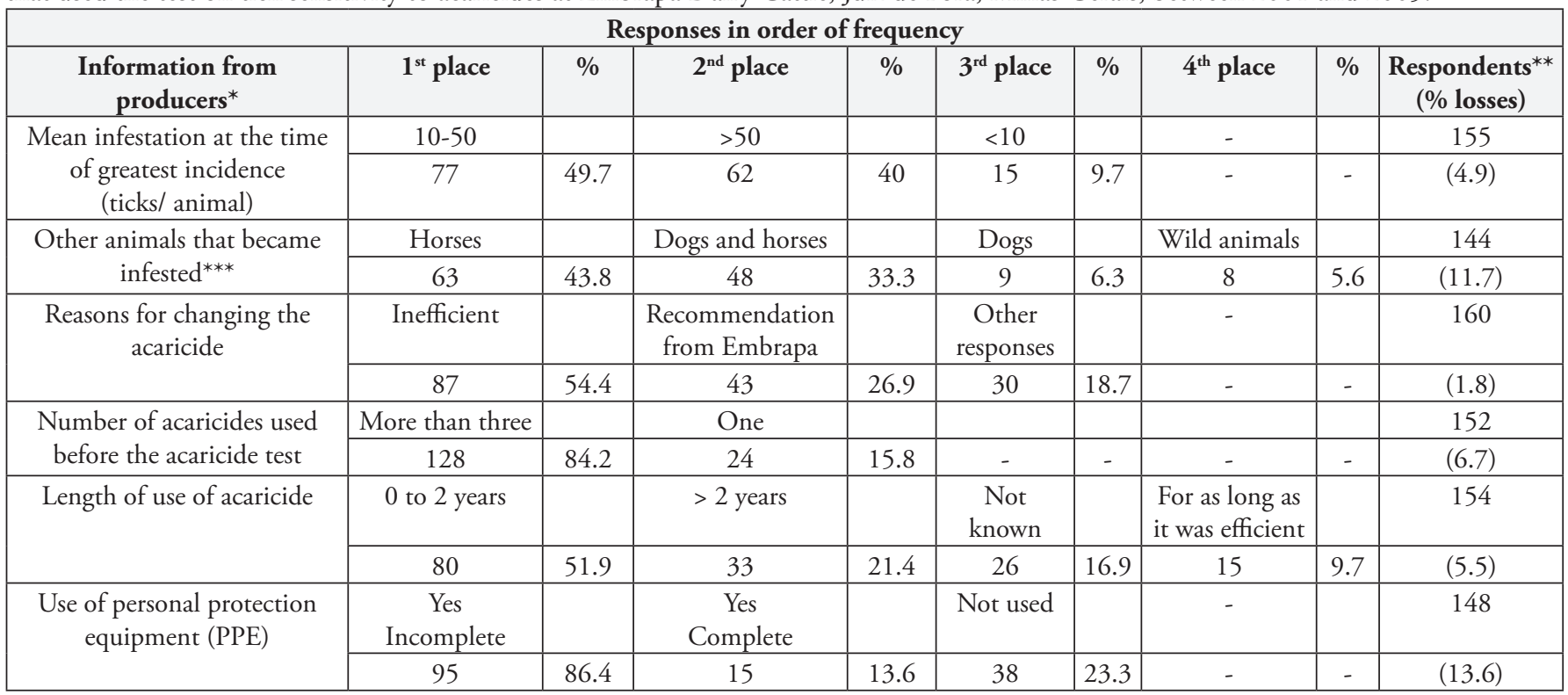

*The percentages do not take losses into consideration; ${ }^{* *}$ Respondents - corresponding to the absolute number of producers that provided information; (\% losses) percentage of questionnaires in which this question remained unanswered, taking $\mathrm{n}=163$; *** $(16) 11 \%$ did not observe infestation in other animals.

Regarding the 38 producers $(23.3 \%)$ that did not use PPE, six $(16 \%)$ justified this in terms of the discomfort caused by the equipment; four (11\%) in terms of lack of habit; and five (13\%) in terms of unawareness. Twenty-three $(60 \%)$ did not answer this question. A hypothesis can be raised that some producers might not have known what PPE is, given that, erroneously, this was not explained in the questionnaire. However, these data are worrying, given that for farm workers performing activities in which toxic products are used, the use of overalls or plastic covers, masks, boots and gloves is recommended (ZOLDAN, 2005). Therefore, the only justifications for not using such equipment when the farm property makes PPE available are lack of knowledge and lack of adequate training. If there is a lack of awareness regarding PPE and the risks of exposure to the products, training should be prioritized (CARVALHO; AMARAL, 2003).

In relation to the acaricide efficiency test (DRUMMOND et al., 1973), only 16 producers (10\%) reported difficulties in obtaining or sending ticks to Embrapa Dairy Cattle. Problems with the postal service and complaints about the cost of sending samples through the post were cited (Table 3 ).

With regard to the service for testing acaricide efficiency against ticks that was provided by Embrapa Dairy Cattle, 93.1\% of the producers considered that it was effective, while $6.3 \%$ rated it poorly, mainly because they had not received the results from the efficiency tests. After receiving the results from the efficiency test, 157 producers (98.7\%) said that they had applied the recommended acaricide. This high rate of acceptance of the product that resulted from the test is a satisfactory result, but for the control process really to be effective, the acaricide also needs to be applied correctly and at the right time.

Associations of pyrethroids with phosphorates (Colosso ${ }^{\oplus}$, Aspersin ${ }^{\circledast}$ ) were the contact acaricides that presented the best efficiency results in the acaricide tests. These associations were recommended for these producers by Embrapa ( $n=47 ; 40.2 \%$ ), followed by associations of phosphorates (Caberson ${ }^{\circledR}$, Ectofós ${ }^{\oplus}$ ) $(\mathrm{n}=45 ; 38.5 \%)$, phenylpyrazoles (Top-line $\left.{ }^{\ominus}\right)(\mathrm{n}=15 ; 12.8 \%)$ and others $(\mathrm{n}=10 ; 8.5 \%)$. Similar results have also been found by several other authors (SOARES et al 2001; ROCHA 2005). Thus, it could be seen that for a large proportion of the farm properties, associations between active agents were the only means for controlling ticks efficiently. This is worrying, because mixtures of active agents increase the chances of poisoning the animals and the acaricide operator, and contaminating the environment and the milk.

Out of the 157 producers that applied the product recommended from the test, $146(93 \%)$ said that they had acquired the product easily, while eight $(5.1 \%)$ encountered difficulties. Because the prices of other products were more affordable, three producers $(1.9 \%)$ chose to buy the recommended product only as the second choice. This demonstrated that most of the products tested by Embrapa Dairy Cattle could easily be found on the market in the regions sampled, and that it was possible to indicate acaricides more rationally, even at a distance. Moreover, out of the 157 producers that affirmed that they had used the acaricides recommended, 144 (92\%) said that they had followed the strategic control. With regard to opinions about strategic control, $79 \%$ of the producers considered that the results were good to excellent, after observing the implementation of the controls.

All the producers participating in the present study were already inclined towards changing their acaricide. For this reason, it would be expected that most of them would follow other recommendations relating to tick control. In addition to asking whether the producer used a control strategy, several questions were asked seeking to understand which real changes had occurred 
Table 3. Perceptions of milk producers that used the test on tick sensitivity to acaricides at Embrapa Dairy Cattle, Juiz de Fora, Minas Gerais, between 2001 and 2005, with regard to the acaricide efficiency test and strategic control over ticks

\begin{tabular}{|c|c|c|c|c|c|c|c|c|c|}
\hline \multicolumn{10}{|c|}{ Responses in order of frequency } \\
\hline $\begin{array}{c}\text { Information from } \\
\text { producers* }\end{array}$ & $1^{\text {st }}$ place & $\%$ & $2^{\text {nd }}$ place & $\%$ & $3^{\text {rd }}$ place & $\%$ & $4^{\text {th }}$ place & $\%$ & $\begin{array}{c}\text { Respondents** } \\
\text { (\% losses) }\end{array}$ \\
\hline \multirow[t]{2}{*}{$\begin{array}{l}\text { Difficulty in sending female } \\
\text { cattle ticks to Embrapa }\end{array}$} & $\begin{array}{l}\text { Acquisition of } \\
\text { female ticks }\end{array}$ & & Postal service & & - & & - & & 16 \\
\hline & 10 & 62.5 & 6 & 37.5 & - & - & - & - & (90) \\
\hline $\begin{array}{c}\text { Opinion on the acaricide } \\
\text { efficiency test }\end{array}$ & Positive & & Negative & & Don't know & & - & & 159 \\
\hline $\begin{array}{l}\text { Application of acaricide } \\
\text { recommended by Embrapa }\end{array}$ & 157 & 98.7 & 2 & 1.3 & - & - & - & - & $(2.5)$ \\
\hline \multirow[t]{2}{*}{$\begin{array}{c}\text { Recommended acaricides } \\
\text { used }\end{array}$} & $\begin{array}{l}\text { Pyrethroids + } \\
\text { Phosphorates }\end{array}$ & & Phosphorates & & Phenylpyrazoles & & Others & & 127 \\
\hline & 47 & 40.2 & 45 & 38.5 & & 12.8 & 10 & 8.5 & $(28.2)$ \\
\hline $\begin{array}{l}\text { Application of acaricide us- } \\
\text { ing backpack pump }\end{array}$ & Yes & & No & & - & & - & & 159 \\
\hline \multirow[t]{2}{*}{$\begin{array}{c}\text { Advantages of strategic } \\
\text { control }\end{array}$} & Lower cost & & $\begin{array}{c}\text { Longer intervals } \\
\text { between spraying } \\
\text { the animals }\end{array}$ & & $\begin{array}{c}\text { Easy to } \\
\text { implement }\end{array}$ & & $\begin{array}{c}\text { Less labor } \\
\text { needed }\end{array}$ & & 138 \\
\hline & 76 & 55.1 & 72 & 52.2 & 68 & 49.3 & 37 & 27 & $(15.3)$ \\
\hline
\end{tabular}

*The percentages do not take losses into consideration; ** Respondents - corresponding to the absolute number of producers that provided information; (\% losses) percentage of questionnaires in which this question remained unanswered, taking $\mathrm{n}=163$; ${ }^{* * *}$ More than one answer to this question was accepted.

on the farm properties and what each producer's understanding about control strategies was.

Out of the 144 producers that followed the guidance to implement strategic control against ticks, 33 (23\%) reported that they had been motivated by confidence in Embrapa Dairy Cattle. The other producers did not answer this question. After using strategic control and the recommended acaricide, 133 producers (92.4\%) affirmed that they had observed a decrease in tick numbers, and $131(91 \%)$ had observed that the animals presented considerable improvements in their general state. According to Rocha (2006), producers wanted to have a control method that would increase the interval between applications, in order to diminish the costs and labor required. Likewise, in the present study, all the 163 producers interviewed pointed out some advantages in using strategic control: 1) 76 (46.6\%) mentioned diminished costs; 2) 72 (44.2\%) cited the longer intervals between spraying the animals; and 3) 37 (22.7\%) cited the ease of operation, which required little labor.

Some studies have concluded that even though tick infestations represent significant losses for milk producers, tick control is also very expensive (JONSSON et al., 2001; LEAL et al., 2003). There are many advantages when the farm owner correctly applies the control strategy, not only for consumers and the milk industry but also for the environment and for delaying the process of establishment of resistance (FURLONG et al., 2007).

Among the 133 respondents $(81.6 \%)$ that noted a decrease in the number of tick attacks on the cattle after implementing the strategic control, some of them highlighted other advantages that they had noted, such as: diminished cost ( $\mathrm{n}=75 ; 56 \%)$; increased intervals between spraying the animals ( $\mathrm{n}=70 ; 52.6 \%)$; and diminished need for labor $(n=35 ; 26 \%)$. Furthermore, 130 producers $(79.8 \%)$ out of those that noted improvements in the animals after implementing the strategic control also observed advantages such as diminished cost $(\mathrm{n}=72 ; 55 \%)$; increased intervals between spraying the animals $(\mathrm{n}=68 ; 52 \%)$; and diminished need for labor $(n=35 ; 27 \%)$.

In the present study, it was observed that backpack pumps were the equipment most used by these producers, on 135 (84.9\%) of the farm properties studied. Similar results were found by Rocha (2005) and Santana et al. (2001). One of the critical factors relating to acaricide spraying is that if the equipment is used inappropriately, this may limit the effectiveness of the spray treatment. Thus, if the quantity of acaricide solution is insufficient to cover the animal's entire body area, the ticks will not be killed (FURLONG et al., 2007). When asked to describe the procedure of acaricide spraying, out of the 46 producers $(28 \%)$ that answered the question, only 29 (63\%) described it correctly (Table 4).

It is emphasized that among the producers that said that they were following strategic control (144 producers), only 29 (54\%) of them correctly described the treatment program recommended by Embrapa Dairy Cattle (FURLONG; PRATA, 2003b).

When asked to describe how to dilute the product, out of the total number of respondents $(n=32), 29(90.6 \%)$ stated that they followed the instruction sheet correctly, and this was confirmed through the responses to the questionnaire. Only 12 producers (7\%) answered all the questions relating to strategic control correctly. This demonstrates that out of the 144 producers who believed that they were following strategic control (Table 3), only $12(8.3 \%)$ were capable of grasping all of the content through the material that was sent to them. 
Table 4. Perceptions of milk producers that used the test on tick sensitivity to acaricides, regarding spraying the animals with acaricide.

\begin{tabular}{|c|c|c|c|c|}
\hline \multirow{2}{*}{$\begin{array}{l}\text { Characteristics* } \\
\text { Form of acaricide application } \\
\end{array}$} & \multicolumn{2}{|c|}{ Categories } & \multirow{2}{*}{$\begin{array}{c}\begin{array}{c}\text { P value } \\
\text { (OR) }\end{array} \\
>0.05\end{array}$} & \multirow{2}{*}{$\begin{array}{c}\begin{array}{c}\text { Respondents* } \\
\text { (\% losses) }\end{array} \\
46 \\
\end{array}$} \\
\hline & Correct & Incorrect & & \\
\hline Modified & 18 & 14 & - & - \\
\hline Not modified & 11 & 3 & - & - \\
\hline Total & $29(63 \%)$ & $17(37 \%)$ & - & $(72)$ \\
\hline Interval between acaricide applications & Correct & Incorrect & 0.02 & 54 \\
\hline Modified & 27 & 17 & - & - \\
\hline Not modified & 2 & 8 & - & - \\
\hline Total & $29(54 \%)$ & $25(46 \%)$ & - & $(67)$ \\
\hline Dilution of acaricide & Correct & Incorrect & $>0.05$ & 32 \\
\hline Modified & 21 & 3 & - & - \\
\hline Not modified & 8 & - & - & - \\
\hline Total & $29(90.6 \%)$ & $3(9.4 \%)$ & - & $(80)$ \\
\hline
\end{tabular}

${ }^{*}$ The percentages do not take losses into consideration; ${ }^{* *}$ Corresponds to the absolute number of producers that provided information; ${ }^{* * *}$ Fisher test.

\section{Conclusion}

The results from this investigation and the analyses performed show that almost all of the producers had difficulty in understanding the parameters required for implementing strategic control against cattle ticks.

In order to obtain real improvements in tick control within the sphere of milk-producing farm properties, i.e. for the technology available to be used correctly, there is a need to seek effective improvements in communication between researchers, public and private agents and rural producers, and to establish training of a more adequate nature for producers.

\section{References}

ANGUS, B. M. The history of the cattle tick Boophilus microplus in Australia and achievements in its control. International Journal for Parasitology, v. 26, n. 12, p. 1341-1355, 1996. http://dx.doi. org/10.1016/S0020-7519(96)00112-9

BARDIN, L. Análise de conteúdo. Lisboa: Edições 70, 1977.

CARVALHO, P. R.; AMARAL, M. A. Z. Biossegurança na Universidade. In: VALLE, S.; TELLES, J. L. (Orgs.). Bioética e Biorrisco. Rio de Janeiro: Editora Interciência, 2003. p. 413-417. v. 1.

CHEVILLON, C. et al. Accumulation of acaricide resistance mechanisms in Rhipicephalus (Boophilus) microplus (Acari: Ixodidae) populations from New Caledonia Island. Veterinary Parasitology, v. 147, n. 3-4, p. 276-288, 2007. PMid:17560723. http://dx.doi.org/10.1016/j. vetpar.2007.05.003

DRUMMOND, R. O. et al. Boophilus annulatus and B. microplus: laboratory tests of insecticides. Journal of Economic Entomology, v. 66 , n. 1, p. 130-133, 1973. PMid:4690254

FREITAS, D. R.; POHL, P. C.; VAZ JUNIOR, I. S. Caracterização da resistência para acaricidas no carrapato Boophilus microplus. Acta Scientiae Veterinariae, v. 33, n. 2, p. 109-117, 2005.

FURLONG, J.; MARTINS, J. R. Resistência dos carrapatos aos carrapaticidas. Juiz de Fora: CNPGL-EMBRAPA, Embrapa Gado de Leite - ACE, 2000. (Boletin Técnico, 59).
FURLONG, J.; PRATA, M. C. A. Resistência dos carrapatos aos carrapaticidas. Instruçáo Técnica para o Produtor de Leite, n. 34, 2003a.

FURLONG, J.; PRATA, M. C. A. Controle estratégico do carrapato dos bovinos de leite. Instruçáo Técnica para o Produtor de Leite, n. 38, 2003b.

FURLONG, J.; MARTINS, J. R.; PRATA, M. C. A. O carrapato dos bovinos e a resistência: temos o que comemorar? A Hora Veterinária, v. 159, p. 26-32, 2007.

GEORGE, J. E.; POUND, J. M.; DAVEY, R. B. Chemical control of ticks on cattle and the resistance of these parasites to acaricides. Parasitology, v. 129, p. S353-S366, 2004. PMid:15938518. http://dx.doi.org/10.1017/S0031182003004682

GRISI, L. et al. Impacto econômico das principais ectoparasitoses em bovinos no Brasil. A Hora Veterinária, v. 21, n. 125, p. 8-10, 2002.

HONER, M. R.; BIANCHIN, I.; GOMES, A. Mosca dos chifres: histórico, biologia e controle. Campo Grande: Embrapa CNPGC, 1990.34 p.

JONSSON, N. N.; MATSCHOSS, A. L. Attitudes and practices of Queensland dairy farmers to the control of the cattle tick, Boophilus microplus. Australian Veterinary Journal, v. 76, n. 11, p. 746-751, 1998. PMid:9862066. http://dx.doi.org/10.1111/j.1751-0813.1998. tb12306.x

JONSSON, N. N.; DAVIS, R.; DE WITT, M. An estimate of the economic effects of cattle tick (Boophilus microplus) infestation on Queensland dairy farms. Australian Veterinary Journal, v. 79, n. 12, p. 826-831, 2001. PMid:11837904. http://dx.doi. org/10.1111/j.1751-0813.2001.tb10929.x

JONSSON, N. N.; HOPE, M. Progress in the epidemiology and diagnosis of amitraz resistance in the cattle tick Boophilus microplus. Veterinary Parasitology, v. 146, n. 3-4, p. 193-198, 2007. PMid:17448604. http://dx.doi.org/10.1016/j.vetpar.2007.03.006

LEAL, A. T.; FREITAS, D. R. J.; VAZ JUNIOR, I. S. Perspectivas para o controle do carrapato bovino. Acta Scientiae Veterinariae, v. 31, n. 1, p. 1-11, 2003.

MENDES, M. C., PEREIRA. J. R.; PRADO, A. P. Sensitivity of Boophilus microplus (Acari: Ixodidae) to pyrethroids and organophosphate 
in farms in the Vale do Paraíba region, São Paulo, Brazil. Arquivos do Instituto Biológico, v. 74, n. 2, p 81-85, 2007.

MILKPOINT. Disponível em: <http://www.milkpoint.com.br/mn/ top100_2001>. Acesso em: 20 abr. 2011.

MINAYO, M. C. S. O desafio do conhecimento: pesquisa qualitativa em saúde. 9. ed. São Paulo: Hucitec, 2006. 406 p.

ROCHA, C. M. B. M. Caracterizaçáo da percepçáo dos produtores de leite do município de Divinópolis/MG sobre a importância do carrapato Boophilus microplus e fatores determinantes das formas de combate utilizadas. 1995. 205 f. Dissertação (Mestrado)-Escola de Veterinária, Universidade Federal de Minas Gerais, Belo Horizonte.

ROCHA, C. M. B. M. Percepçáo e Atitude de Produtores de Leite de Minas Gerais de Diferentes Extratos de Produçáo em relaçáo ao Boophilus microplus. 2005. 65 f. Tese (Doutorado)-Escola de Veterinária, Universidade Federal de Minas Gerais, Belo Horizonte.

ROCHA, C. M. B. M. et al. Percepção dos produtores de leite do município de Passos, MG, sobre o carrapato Boophilus microplus (Acari: Ixodidae), 2001. Ciência Rural, v. 36, n. 4, p. 1235-1242, 2006. http://dx.doi.org/10.1590/S0103-84782006000400029

ROJAS, R. A. O. El Cuestionario. 2001. Disponível em: <http://www. nodo50.org/sindpitagoras/Likert.htm>. Acesso em: 22 nov. 2004.

SANTANA, V. L. A. et al. Diagnóstico de situaçáo de Controle Químico do carrapato dos bovinos em propriedades das mesorregióes da mata e agreste do estado de Pernambuco - Brasil. Ciência Veterinária dos Trópicos, v. 4, n. 2-3, p. 281-290, 2001.
SANTOS JUNIOR, J. C. B.; FURLONG J.; DAEMON, E. Controle do Carrapato Boophilus microplus (Acari: Ixodidae) em Sistema de produção de Leite da Microrregiáo Fisiográfica Fluminense do Grande Rio Rio de Janeiro. Ciência Rural, v. 30, n. 2, p. 305-311, 2000.

SOARES, V. E. et al. Análise in vitro de carrapaticidas em cepas de Boophilus microplus (Canestrini, 1887) colhidas de bovinos leiteiros da região nordeste do Estado de São Paulo. Semina: Ciências Agrárias, v. 22, n. 1, p. 85-90, 2001.

SOUZA, A. P. et al. Eficácia de Carrapaticidas em Rebanhos de Bovinos Leiteiros de Municípios da Região Centro Sul do Paraná. Revista de Ciências Agroveterinárias, v. 2, n. 2, p. 245-250, 2003.

THULLNER, F.; WILLADSEN, P.; KEMP, D. Acaricide Rotation Strategy for Managing Resistance in the Tick Rhipicephalus (Boophilus) microplus (Acarina: Ixodidae): Laboratory Experiment with a Field Strain from Costa Rica. Journal of Medical Entomology, v. 44, n. 5, p. 817-821, 2007. http://dx.doi.org/10.1603/0022-2585(2007)44[817:ARSFMR]2 .0. $\mathrm{CO} ; 2$

VERÍSSIMO, C. J. et al. Infestação por carrapatos Boophilus microplus (Acari: Ixodidae) em vacas jersey. Arquivos do Instituto Biológico, v. 71, p. 1-749, 2004. Suplemento.

ZOLDAN, R. Condiçóes e procedimentos na manipulaçáo de agrotóxicos por trabalhadores rurais. 2005. 105 f. Dissertação (Mestrado)-Centro de Filosofia e Ciências Humanas, Universidade Federal de Santa Catarina, Florianópolis. 